\title{
Business evolution in the lens of universities' sustainable impact: Russian lessons in BRICS
}

\section{Zhanna Belyaeva - Victoria Bentsion}

\begin{abstract}
Purpose of the paper: Recent trends in education have brought universities to new qualitative levels of communicating education globally. The newly evolved roles of universities include sustainable mentoring and introducing socially responsible graduates to the global job market. University social responsibility is a fast growing theory derived from the general concept of corporate social responsibility, which considers special multistakeholder responsibility within higher education institutions (HEIs). The existent literature still lacks a consistent study of the necessary cultural context for the development of social impact and innovation sources in emerging economies' universities. To fill in the gap this paper aims to analyze the heterogeneity of the intended social impacts of BRICS universities in terms of regional business evolution.
\end{abstract}

Methodology: The research design employs adjusted explorative methodology to justify USR application and casual methodology to study USR models applied to a stratified sample of 10 internationally ranked BRICS universities. We have analyzed the textual sources of internal and external communication of USR in accordance with a specifically predefined coding system.

Findings: The results of the research have revealed same knowledge drivers of USR in BRICS countries. Nevertheless, the cross-cultural context varies, so while some countries persuade ecological and strategic development by using sustainable management, Russian HEIs put more stress on classical educational roles and promotional activities.

Research limits: The size of the sample entails some limitations.

Practical implications: The authors suggest glocalised knowledge-management for future managers' sustainable strategy choice. Moreover, some results may be applied as a guideline to modify sustainable development.

Originality of the paper: The novel framework of USR in BRICS universities represents a new category for further theoretical and practical implications.

Key words: university social responsibility; BRICS; non-financial reporting, sustainable impact

\section{Introduction}

A socially responsible approach has become the inevitable part of sustainable economic and social development. In the global context, the term 'social responsibility' is still often associated with large corporations. In truth though, social responsibility theory evolution has brought a wider understanding of its application. 
sinergie Vol. 35, N. 102, 2017

The socially responsible role of universities has given rise to many discussions in the academic world. Currently, the university's function is not only to train students for various vocations, but also to enhance social relevance, rather than simply issuing diplomas, to encourage students to find their own direction and think beyond individual interests towards societal interest. This means that through socially responsible behavior universities demonstrate that they know and can respond to current social issues both through personal projects related to community development and through educational programs, which educate young people to become socially responsible individuals and equal participants in creating positive social change.

University social responsibility is a new trend of the general theory of organizations' responsibility (Gomez, 2014). The term "social responsibility" is based on the legal and ethical obligations that arise from corporate activities and may affect society, economy and the environment. In considering universities as an organization, we can argue that this category is also responsible for their actions to various stakeholder groups (students, staff, alumni, community, and environment). In addition, universities, through their main function, i.e. training, should be an example of ethical behavior, fair management, transparency and respect for human rights.

Higher education institutions have a unique role in ensuring sustainable development of regions, since the list of their commitments includes the promotion of responsible knowledge and practice. Universities are responsible for helping students in the formation of certain skills involving the understanding of the importance of social responsibility and sustainable development (Matten and Moon, 2004). Thus, we can conclude that higher education institutions have an obligation towards society for the education of future socially responsible leaders, which, in turn, should become the drivers of sustainable regional development.

In addition, universities are becoming increasingly important participants in the creation of sustainable social development because connecting the learning process with economic activities can affect the creation of sustainable dynamics of economic and social development in the community in which the university is active (Etzkowitz, 2012).

The relevance of social responsibility in higher education institutions is backed by several global trends. The first visible trend is the constantly growing number of enrolled students (Vasilescu et al., 2010). This means that more and more people have the opportunity to enter HEIs at different times of their adult life. The trend of the growing number of students is shown in Fig. 1. 
Fig. 1: Total number of students in the world successfully completing tertiary education programs (thousands)

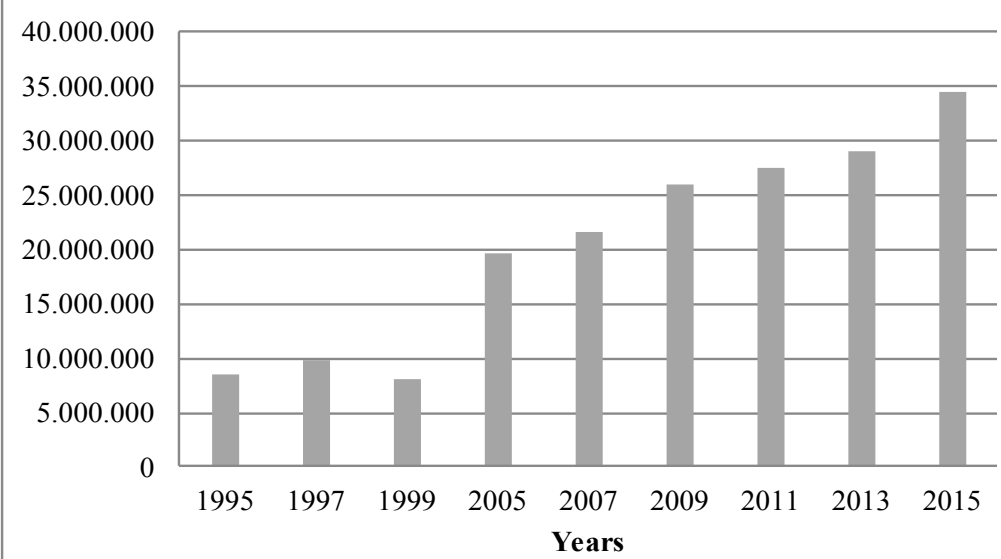

Zhanna Belyaeva

Victoria Bentsion

Business evolution in

the lens of universities sustainable impact:

Russian lessons in BRICS

Source: UNESCO Institute for Statistics, 2016

According to UNESCO's Global Education Digest (2011), the capacity of the world's education systems has more than doubled in almost 43 years. Comparing absolute numbers in 1995 with those in 2013, it is possible to see that the number of tertiary students greatly increased and that East Asia and the Pacific are the regions that lead the way.

The second trend consists in the globalization and internationalization of universities. There is no questioning the fact that student mobility was not common for most universities in the past. However, in the last 10 years the number of students studying outside of their home countries has increased greatly. Unfortunately, data are difficult to obtain and verify, but UNESCO research shows that in 2007 there were more than 2.8 million international students (compared to 1.8 million in 2000). According to forecasts, by 2025, almost 7.2 million students may be studying internationally (UNESCO's Global Education Digest, 2009). At the university level, globalization can be reflected in the way many universities have stated international missions, aiming to produce "global citizens" with "global competencies".

The third trend is derived from the second - i.e., universities are becoming more active participants in different spheres of activity. Higher education institutions are no longer supposed to operate in isolation; rather, they are now interactive players who work closely not only with the industry, but also with their community and government. They are an inevitable part of national or regional innovation systems (Mowery and Sampat, 2005).

The forth trend concerns knowledge dissemination in different crosscultural contexts, which requires innovative models of communicating key strategies to the global arena (Del Giudice et al., 2012). 


\section{sinergie}

Vol. 35, N. 102, 2017

\section{The genesis of the USR concept}

The concept of university social responsibility has emerged relatively recently. In 2001, several Latin American universities working in partnership with the Inter-American Development Bank developed a project, which was called "Ethics, Social Capital and Development". This initiative helped to raise awareness of the importance of social practices beyond traditional volunteer outreach programs. The concept of university social responsibility arose within this project. Higher educational institutions in Latin America later declared the importance of this theory.

Despite its initial stage of development, the concept of university social responsibility is characterized by a considerable number of definitions. One of the first explanations of USR was developed by a network of universities in Chile from 2001 to 2005. According to this group of higher education institutions, USR represents the ability to create and promote a group of principles and values through the development of management processes, training, research and community outreach (Gomez, 2014). Another definition suggests that social responsibility of higher education institutions is a policy of ethical quality of the performance of the university community (students, faculty and administrative employees) through the responsible management of the educational, cognitive, labour and environmental impacts produced by the university in an interactive dialogue with society to promote sustainable human development (as cited in Vasilescu, et al., 2010).

Moreover, German scientists developed a concept similar to USR, - known as Institutional Social Responsibility (ISR) (Stark et al., 2014). The ISR concept is based on the following new requirements for higher education: social learning; leadership, community and team building skills; civic education; sensibility of challenges in society; awareness of social responsibility.

Besides, the literature overview has revealed another approach to define university social responsibility. It is a philosophy or principle for social movement, which can be perceived as a university's philosophy to use an ethical approach to develop and engage with the local and global community in order to sustain social, ecological, environmental, technical and economic development (Esfijani et al., 2013).

In addition, researchers emphasize the differences between the concept of corporate social responsibility (CSR) and the social responsibility of universities. CSR practices cannot be applied to HEIs. The social responsibility of universities considers other specific impact factors, which corporations are not aware of, such as educational and cognitive ones (as cited in Gomez, 2014). The business concept of corporate social responsibility cannot cover all of social responsibility (Stark et al., 2014).

Other characteristics of sustainable and socially responsible universities include leadership and vision, which promote needed change, accompanied by a proper assignment of responsibility and rewards. This assignment of responsibility is committed to a long-term transformation of the universities which are willing to be responsive to society's changing needs (Lozano, 2006). 
The social responsibility of universities refers not only to staff training and socially responsible citizens, but also raises issues of economic, social and cultural development, as well as participation in the promotion of social justice (Berezo et al., 2010). In this sense, the practice of social responsibility of higher education institutions is an interdisciplinary activity involving professors, researchers, deans, students and external universities' stakeholders, based on ethical management, teaching, and training (Vasilescu et al., 2010).

Besides, university social responsibility can be explained as the ability to disseminate and practice a set of pillars and values through four key activities: management, education, research and additional activities (as cited in Lozano, 2006). The author of this definition supposed that universities should found their academic and organizational responsibility on ethical theories that will connect with satisfying the needs of the community in which they operate. According to Jimenez de la Jara, the social responsibility of universities must not represent an additional extracurricular activity. Universities have to be responsible on a daily basis, and social responsibility must be part of their personality, ethos and existence.

Taking into consideration all the definitions mentioned above, we may thus summarize the different approaches of USR: it is a specific management theory that requires universities to think in a socially responsible way beyond basic functions like teaching and researching.

The USR concept could help to define the impacts of universities that are important for its internal and external stakeholders. The relevance and importance of university social responsibility is also supported by its inclusion as an object of study to the agenda of the International Association of Universities, and the existence of organizations in this field like the Bentley Alliance for Ethics and Social Responsibility (BAESR) in Boston, Asia-Pacific University-Community Engagement Network.

In addition, in 2005 the Talloires Declaration was drafted in 1990 at an international conference in Talloires, France: this was the first official statement to be made by university administrators concerning commitment to environmental sustainability in higher education. The Talloires Declaration (TD) is a ten-point action plan for incorporating sustainability and environmental literacy in teaching, research and operations and outreach at colleges and universities. It has been signed by over 350 university presidents and chancellors in over 40 countries. According to this Declaration, socially responsible universities should apply the processes of education and research to respond to, serve and strengthen its communities for local and global citizenship. Universities have the responsibility to participate actively in the democratic process and to empower those who are less privileged.

Despite the clear role of universities in the development of economic and social sustainability, many universities fail to respond to the challenges and demands posed by their environment. Most of them, according to Wesheimer still succumb to pressuring students and their parents in order to prepare them for their professional career, personal growth and economic gain but neglecting the importance of creating active and engaged citizens as well (as cited in Peric, 2012).
Zhanna Belyaeva

Business evolution in

the lens of universities'

ustainable impact:

Russian lessons in BRICS 
sinergie Vol. 35, N. 102, 2017

In fact, all HEIs inevitably face challenges and problems during their transformation into socially responsible universities. Velazquez et al. (2005), in their study of the factors that presented several issues that negatively influence sustainability initiatives, list the following: lack of awareness/ interest/knowledge and involvement of individuals, organizational structure, time and funding constraints, lack of support from top management, lack of suitable communication and information, resistance to change, lack of more rigorous regulations, lack of interdisciplinary research at the university, lack of performance indicators, lack of policies and variety of technical problems. Another group of researchers has revealed one more group of barriers: financial, bureaucratic, cultural, and individual (Nejati et al., 2011).

\section{The interaction of universities and regions: methodology overview}

There is no questioning the fact that each organization has inevitable impact on its home region. Currently, there are many approaches determining the patterns of interaction of universities and regions, especially concerning the impact of higher education institutions on regional development.

At the most basic level, universities can be the anchor institution within the local economy as a major employer in a wide range of specializations, buyers of local goods and services, and contributors to cultural life and the built environment of cities and towns. Regional investment in university infrastructure in order to support its core business of research and teaching can therefore have a significant impact on regional conditions even if the university is not actively supporting regional development.

Nevertheless, considering universities through the social responsibility prism, there are other possible effects on regions. It should be noted that approaches to the determination of universities' impact on regional development might vary, along with the definition of the USR concept.

Some authors divide the possible effects of higher educational institutions' activities into negative and positive ones (Gomez, 2014). For example, inadequate working conditions, lack of ethics courses, indifference to social problems and outdated educational programs may be considered negative factors. In contrast, positive factors include ethical and transparent management system, interdisciplinary courses, continued dialogue with the various stakeholder groups, etc.

In addition, researchers presented the way of defining universities' impact on regions through the well-known Triple Bottom Line concept. Universities should also operate in accordance with Triple Bottom Line paradigm and assess their own possible impacts on regions through TBL lens. Higher education institutions are expected not only to be oriented towards economic profit, but also to be concerned with environmental sustainability (planet) and the welfare of society (people); universities should also pay more attention to the interaction and impact of its activities on all stakeholders. In some senses, the TBL is a particular manifestation of a balanced scorecard. 
Likewise, the academic literature suggests a model entitled Sustainability in Higher Education Institutions (SusHEI) that generally describes and characterizes the functioning of a HEI (Madeira et al., 2011). This model is based on one of the core activities of any university, like education and research, and took HEIs' impacts at economic, environmental and social levels, and the role of its community into account.

Besides, some authors propose quite practical systems combining five areas in which college and university performance can definitely be linked with sustainability: energy use, water use, use of land, purchase of products and their treatment at the end of their useful lives, as well as air, water and land emissions (Graedel, 2002).

In considering national approaches to university social responsibility and its impact on regions, the authors have determined that German universities recommend a specific assessment approach. The questionnaire was developed in order to reveal the perception of different impacts of universities' activity. The authors classified gathered data (possible universities' impacts) into three key groups. The first one is collaboration and personnel exchange, which represents research and collaboration with regional partners, advice and expertise for regional organizations, temporary exchange of personnel between universities and regional partners (interns, professors), and support of final theses developed by students in regional corporations (Koschatzky and Stahlecker, 2010). The second group consists in the supply of resources that reflects permission to use different equipment in universities (laboratories), rooms and other infrastructure provided by universities. In addition, the third group of factors is social engagement, which represents information and further education for different groups and, in addition, contribution to the social life of the region. It's important to mention that universities in Germany have been carrying out socially responsible activities through long term partnerships which are institutionalized in different forms with different external stakeholders.

Moreover, UK universities have developed a five-dimensional system of impacts (University of Essex, 2014). The first function of higher educational institution is developing a flexible and adaptable workforce. In fact, a skilled and flexible workforce is central to economic development. Businesses are increasingly reliant on higher levels of skills to drive innovation, improve management and facilitate investment. The university takes its responsibilities for equipping the workforce of tomorrow to meet the needs of businesses seriously. The second point is supporting regional innovation and competition that requires universities to provide relevant forecasts, up-to-date research and to obtain patents and licenses. The next direction is accelerating economic development. Under this function universities impact upon economic development in a range of ways, from producing highly skilled graduates and research-trained individuals that are important for a well-functioning knowledge-based economy, to producing advanced knowledge that can help solve economic and social challenges. Universities help create the necessary networks of academics and industrialists that aid the flow of knowledge around the innovation system. Moreover, higher education institutions are a stable and progressive employer. Aside from their teaching and research outputs, HEIs are major commercial operations
Zhanna Belyaeva

Business evolution in

the lens of universities

sustainable impact:

Russian lessons in BRICS 
sinergie Vol. 35, N. 102, 2017

themselves. According to the authors, universities must stand out from other employers as being highly progressive, with a significantly higher-than-average representation of women at professional and managerial levels, as well as being an ethnically diverse employer with an international perspective. The last function of universities is meeting social responsibilities. Universities contribute to societal development both directly, through active outreach to their local communities, and indirectly through research, teaching and knowledge exchange activities.

Moreover, OECD classified the possible impacts of HEIs into 4 groups: regional innovation which is closely linked to the research function of universities; human capital development, linked to the teaching function; social and cultural development, associated with the public service role of universities; and the contribution of universities to the institutional capacity of the region through the engagement of its management and members in local civil society. If these four directions shown in the graph are integrated, universities can be seen as occupying a "proactive", and not just a "passive", role in the regional development process.

There is another approach to the classification of the effects of higher education institutions activities on regions. Researchers have proposed to group all the possible consequences of universities' actions into four groups: organizational, cognitive, educational, and social. These groups constitute a model of social responsibility of universities that is also based on the above mentioned 4-way impacts.

Obviously, organizational and social impacts can be reflected in any type of organization because every organization hires people, has environmental impact and, to some extent, interacts with the local community. However, educational and cognitive impacts are specific to the academic system, since universities are directly responsible for the professional education of the population, as well as for the development of the research base.

In addition, we need to consider a modified model of social responsibility of higher education institutions (Belyaeva, 2015). The author of this model proposed to group the university's impacts into 4 key directions: educational (qualificational), promotional, ecological and cultural (Fig. 2). Promoting factors reflect the development of the business environment and brand recognition. Educational factors include the alignment of the labor market, relevant teaching programs and qualified academic staff. Cultural factors summarize the development of intellectual space as well as the dissemination of the cultural, ethical, social and environmental behavior. The environmental part of the model is dedicated to environmentally safe projects and Green Campus technologies. 


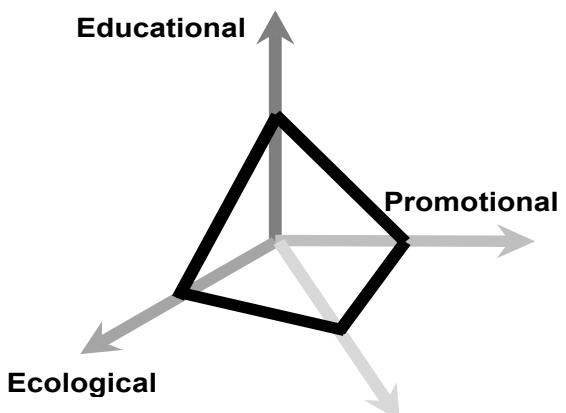

Source: Belyaeva, 2015

Summarizing the above, there are different approaches to combine and assess practices related to university social responsibility and universityregion interrelations. The general feature of all these methodologies is the idea of classifying the activities of HEIs into categories and measuring their impact. The categories are similar in some systems. This paper will follow the logic of driver-based USR model (Belyaeva, 2015). This methodology allows the defining of a range of impacts of HEIs on regions and its comparison among countries of research. In addition, cultural aspects are designated separately, which is of particular importance within internationalization education processes. The promotional group of factors must also be examined.

\section{The impact of universities on regional development}

\subsection{The BRICS universities sample}

In this paper, we analyze and compare universities' influence on regional development through the review of practices in the selected institutions according to Belyaeva's model. We have used case analysis as the most appropriate method for comparing universities, then applied content analysis to collect the data as described below. The research is limited by its sample size, but that is to create prerequisites for the future expansion of the study's research scope.

The sample consists of ten leading universities in BRICS, confirmed by their presence in internationally approved global education rankings: University of São Paulo, Federal University of Rio de Janeiro (Brazil), SaintPetersburg State University, Ural Federal University named after B. N. Yeltsin (Russia), Indian Institute of Science Bangalore, Indian Institute of Technology Delhi (India), Tsinghua University, Peking University (China), University of Cape Town, University of Johannesburg (South Africa) (Tab. 1). The sample of universities that was analyzed in this paper was predefined in accordance with specific criteria: The universities' being members of the QS World University Ranking; as geographic criteria, their institutions' home 
sinergie

italian journal of management Vol. 35, N. 102, 2017

countries being BRICS members; and the GRI-criteria, which requires universities to provide a social responsibility report or sustainability report based on GRI recommendations (optional).

Tab. 1: Universities' sample

\begin{tabular}{|l|c|c|c|c|c|c|}
\hline \multirow{2}{*}{ University } & \multicolumn{2}{|l|}{ Number of students } & \multicolumn{2}{l|}{$\begin{array}{l}\text { Number of academic } \\
\text { faculty staff }\end{array}$} & $\begin{array}{l}\text { Position in QS } \\
\text { World University } \\
\text { Rankings }\end{array}$ \\
\cline { 2 - 6 } & In total & International & In total & International & $\# 121$ \\
\hline University of São Paulo (Brazil) & 74787 & 2077 & 5785 & 269 & $\# 311$ \\
\hline $\begin{array}{l}\text { The Federal University of Rio } \\
\text { de Janeiro (Brazil) }\end{array}$ & 54055 & 1216 & 4090 & 226 & $\# 240$ \\
\hline $\begin{array}{l}\text { Saint-Petersburg State } \\
\text { University (Russia) }\end{array}$ & 22283 & 2063 & 4149 & 95 & $\# 491-500$ \\
\hline $\begin{array}{l}\text { The Ural Federal University } \\
\text { named after B.N. Yeltsin } \\
\text { (Russia) }\end{array}$ & 28090 & 956 & 3285 & 82 & $\# 190$ \\
\hline $\begin{array}{l}\text { Indian Institute of Science } \\
\text { Bangalore (India) }\end{array}$ & 3512 & 34 & 504 & 444 & 6 & $\# 172$ \\
\hline $\begin{array}{l}\text { Indian Institute of Technology } \\
\text { Delhi (India) }\end{array}$ & 7399 & 100 & 444 & $\# 25$ \\
\hline Tsinghua University (China) & 34170 & 4029 & 5136 & 880 & $\# 38$ \\
\hline Peking University (China) & 38759 & 5823 & 4810 & 868 & $\# 191$ \\
\hline $\begin{array}{l}\text { University of Cape Town } \\
\text { (South Africa) }\end{array}$ & 19083 & 3051 & 1497 & 369 & 319 & $\# 601-650$ \\
\hline $\begin{array}{l}\text { University of Johannesburg } \\
\text { (South Africa) }\end{array}$ & 19200 & 1479 & 1449 & & \\
\hline
\end{tabular}

Source: QS World University Ranking, 2016

In addition, the authors have conducted a case study analysis in order to consider several examples of USR initiatives of HEIs from the sample. The Federal University of Rio de Janeiro operates in accordance with the university's Development Program of Brazil, which determines the general concept of this institution. The university is guided by the principle of the inseparability of teaching, research and development; the basis for its development is constituted of educational, cultural, scientific and interdisciplinary university activities that promote interaction between universities and other sectors of society.

For initiatives of promotional groups of factors, the university offers international conferences, inviting foreign teachers to cooperate actively and build partnerships with major business players in the country (Petrobras). Cultural initiatives include an active dialogue with the public, aimed to develop relations between the university and social sectors through knowledge exchange. The educational activities of the university, besides training qualified personnel, also involve increasing access to education, which contributes to overcoming inequality and social disproportions and to creating a more ethical society.

The University of São Paulo is one of the most prestigious higher education institutions in Brazil. It also figures among the world's best universities in the QS World University Rankings. Strongly connected 
with the local community, the University of São Paulo runs several hospitals and public service centers. Moreover, this institution can boast strong and efficient research and development departments based on several modern laboratories, where tests and research are carried out. The results of local researchers are constantly implemented in health care and manufacturing processes (optimization of air, water and emissions).

Ural Federal University is currently in the early stages of its implementation of the policy of social responsibility. However, due to the orientation of experts in this area, Ural Federal University is actively working on becoming socially responsible. The university is preparing a social report with a list of socially responsible initiatives. UrFU is implementing international standards during the preparation of this report, including the GRI's Sustainability Reporting Standards (GRI). In addition, this university created Innovative-Implementation Center, which operates in partnership with business representatives and research centers. The above initiatives can be attributed to promotional impacts.

Saint-Petersburg State University operates in accordance with the university's 2020 Development Program. The university announced about 5 prioritized directions: nanotechnology and materials; medicine and health; information systems and technologies; ecology and environmental management; social studies and management skills and technology. According to Saint-Petersburg State University, there is an increasing level of applied research in the field of ecology and environmental management in the university's research center. Moreover, 20 ongoing university research projects will lead to the creation and application of new approaches in health care, climate forecasting, ecosystem, mining, environmental management and reduction of technological impacts. In addition, this university has started research on the human potential of the Russian Federation as a factor, thus determining the alignment of social, economic, migration, humanitarian, cultural, educational, environmental and legislative activity in Russian regions.

The Indian Institute of Science was established in 1909 and has grown into a premier research institution since then, with more than 2000 active researchers working in almost all frontier areas of science and technology. This University is an institute of higher learning and is constantly in pursuit of excellence. It is one of the oldest and finest centers of its kind in India and has a very high international standing in the academic world as well. It is remarkable that its department of Biotechnology gives new incentive to the development of the fields of modern biology and biotechnology in India. In the last sixteen years, the department has promoted and accelerated the pace of the development of biotechnology in the country. In addition, safety issues and gender inequality problems are of particular importance in the Indian Institute of Science. For example, the institute is committed to maintaining gender equality on and outside of campus. It ensures that female students and staff have no gender related tensions and feel completely safe to live and work on campus. There are also many cross-cultural and ethical courses in Indian Institute of Science's degree programs.

The goals of the Indian Institute of Technology are to contribute to India and the world's progress through excellence in scientific and technical
Zhanna Belyaeva

Business evolution in

the lens of universities

sustainable impact:

Russian lessons in BRICS 
sinergie Vol. 35, N. 102, 2017

education and research; to serve as a valuable resource for industry and society; and remain a source of pride for all Indians. There are many regular workshops and conferences on the cultural and ethical problems of Indian regions that are focused on inequality problems. In addition, they provide a variety of research centers, for example medicine and health care, cyber systems and information, environment protection center. Moreover, the university has been developing education programs for employed engineers and making them available both on campus and by means of distance learning techniques at off-campus locations. The Indian Institute of Technology provides many resources (technological, information and human) to anticipate India's technological needs and therefore plan and prepare to cater to them.

Tsinghua University is constantly first place in the national rankings of Chinese universities. For many years, this university has been paying great attention to international cooperation, the exchange of experience, technology and the promotion of the university's achievements in China and abroad. In addition, Tsinghua is actively working towards the protection of the environment, as may be seen by the Green Campus concept that has been in practice for more than 20 years. The university took part in 280 environmental projects at a national level and 300 patents related to sustainable development are registered by Tsinghua researchers. Moreover, there is Center for Innovation and Social Responsibility, which deals with internal and external social projects and provides new courses for educational programs.

Peking University (PKU) is a comprehensive and national key university. PKU is also a member of "Social Responsibility Network". This league upholds the common educational idea of international universities that students should improve their social responsibility and personal ability through voluntary service. Membership of this league allows universities to facilitate students exchange and get strong financial support. Besides, Peking University's location provides an opportunity to create partnerships with successful companies that are based in this region. PKU seeks to cultivate productive cooperative relationships with local corporations. All the programs and courses provide applied-oriented approaches and technologies.

The University of Cape Town stands out from the sample due to the existence of an annual report issued in accordance with the GRI. In addition, this annual research report, including key research projects and their results, is also available on the university's website and contains topical sections describing student participation in solving problems of social inequality and security. The University of Cape Town takes part in environmental projects related to the African Climate \& Development Initiative and its research facilities contribute significantly to the development of science and medicine.

The University of Johannesburg is true to its African roots and well prepared for its role in realizing the potential that higher education holds for the continent's development. There is complex and well-designed system of different research centers in the University of Johannesburg. Its facilities, such as the Process, Energy and Environmental Technology Station and 
Techno Lab allow researchers to carry out a variety of tests and studies, whose results are implemented by plants and manufacturing companies in this region. The Laser Research Centre is devoted to contemporary health care studies and its findings are adopted and implemented by medical centers in South Africa.

\subsection{Methodology}

We have carried out a content analysis of documents, websites and schedules, as well as additional information resources of the chosen universities in order to classify all initiatives into the 4 main directions of the driver-based model.

The tool used for such content analysis is a widely used qualitative research technique in the field of CSR research analyzing non-financial reports and websites. It is a process of gathering and codifying both qualitative and quantitative information into predefined categories. In accordance with existing similarities between CSR and USR, content analysis has been chosen as the methodological approach of the present paper.

The aim of the content analysis is to build a model of USR in BRICS using textual information. In qualitative content analysis the category systems are inductively developed out of concrete material or deductively put together individually for the specific study. In this pilot research, it was determined that the 4 main directions of the driver-based model (Belyaeva, 2015) could be used as initial coding categories. In this moment, the predetermined categories (promotional, educational, cultural, and ecological) matched the 4 groups of impacts.

Moreover, content analysis requires great samples of text information. Most higher education institutions from the list in this paper are supposed to issue reports devoted to the university's sustainable development program or research projects, along with its aims and results. Unfortunately, the situation appeared to be the opposite: only the University of Cape Town has social responsibility report based on GRI recommendations. This report is issued every 2 years and represents a well-structured document including a great amount of data related to the USR of Cape Town University and its interrelations within the entire country.

Besides, the UrFU (Russia) along with Peking University provides guidelines on their Social Responsibility Policy. In addition, the websites of all the universities (except for the Indian Institute of Science, the Indian Institute of Technology and Tsinghua University) provide schedules that allow us to be informed on the educational programs of these HEIs.

Likewise, there are many specialized centers or departments devoted to different activities (economic, health, sustainable development, innovation, culture, research, IT, environment), that represented significant sources of information for our research. These resources are well represented at the webpages of Saint-Petersburg State University, Indian Institute of Science, Indian Institute of Technology, University of Cape Town and University of Johannesburg.

In addition, the authors gathered some information from other resources such as articles devoted to the comparative analysis of universities' practices (Tsinghua, Ural Federal University) (Zou et al., 2015, Belyaeva, 2015).
Zhanna Belyaeva

Business evolution in

the lens of universities

sustainable impact:

Russian lessons in BRICS 
sinergie Vol. 35, N. 102, 2017

Eventually, our methodology is based on 2 blocks of data: analyzing internal documents (schedules, website content, reports, programs, guidelines, and conference announcements) and external resources (common national guidelines, comparative analysis in academic literature).

\subsection{Findings: various aspects of USR in BRICS countries}

As discussed above, predefined codifying categories were determined in accordance with the driver-based model. The promotional group of factors reflects the role of universities in the economic and business fields. In addition, brand awareness and brand recognition are considered in this category. International science and business conferences and meetings held at universities can draw attention and attract investments to the universities' regions. Moreover, such events create an important/a promising environment for networking. The signal words determined for promotional category are the following: "public, interrelations, partnership, endorsement, socio-economic investment, labor standards, networking, and conference".

The next category is education, which represents the basic functions and responsibilities of universities. The first and key role of HEIs is to train students for various vocations and satisfy regional requirements in skilled and efficient human resources. However, in the current new era of socially responsible universities, institutions are endowed with the new role of training and creating socially responsible personnel and, possibly, future socially responsible managers. Accordingly, the following signal words were chosen: "learning program, sustainable economics, sustainable management, corporate social responsibility, corporate governance, subjects, schedule, disciplines, academic publishing, articles, collaboration, curriculum, study levels, academic degree, knowledge exchange, vocational education".

In the first part of this paper, the trends of transforming universities' roles were discussed. The second trend consists in the globalization and internationalization of universities. Consequently, the crosscountry activities of institutions (student exchanges, international projects, professional collaboration) inevitably disclose different cultural discrepancies. Therefore, a cultural codifying category combines HEIs' impact on regional cross-cultural problems and peculiarities. Moreover, the information related to this category represents different projects and activities devoted to human rights protection, which could find further implementation in the regional policy or labor standards of the regional business environment. The authors selected expressions like "crosscultural peculiarities, art, protection of human rights, women's rights, different races, international students, international professors, cultural differences, non-discrimination and equal opportunities" as signal words for the "Cultural factors"category.

There is no questioning the fact that the environmental or ecological component is represented in almost every USR and CSR model. Our case study analysis has revealed that BRICS HEIs are also involved in a variety of regional and international environmental projects. Several universities in 
BRICS collaborate with business representatives and develop technological and managerial approaches devoted to environment friendly production. The following signal words were defined for this codifying category: "ecology, environment, health, low carbon technologies, environment friendly, air pollution, environmental protection, waste management, green campus, green university".

The data analysis started with computer-assisted searches for the occurrences of the signal words in the chosen textual resources. The quantity of rows with predetermined signal words (word partnerships) were calculated and compared to the total number of rows of text resources (by country).

Tab. 2: Results of content analysis

\begin{tabular}{|c|c|c|c|c|}
\hline Countries & Promotional & Educational & Cultural & Ecological \\
\hline Brazil & $30 \%$ & $50 \%$ & $15 \%$ & $5 \%$ \\
\hline Russia & $40 \%$ & $35 \%$ & $5 \%$ & $10 \%$ \\
\hline India & $15 \%$ & $29 \%$ & $30 \%$ & $26 \%$ \\
\hline China & $10 \%$ & $20 \%$ & $10 \%$ & $60 \%$ \\
\hline South Africa & $5 \%$ & $15 \%$ & $35 \%$ & $45 \%$ \\
\hline
\end{tabular}

Source: our findings

In order to visualize the results, each category was represented as a percentage value ( $100 \%$ - total quantity for country). According to the results of the content analysis, a USR model of the BRICS countries' universities was created (fig. 3). This graph reflects our first observations based on content analysis. In relation to our findings it is possible to see that all 4 directions of the impact-based model are represented at the different levels.

Fig. 3: Impact-based USR Model of BRICS' universities

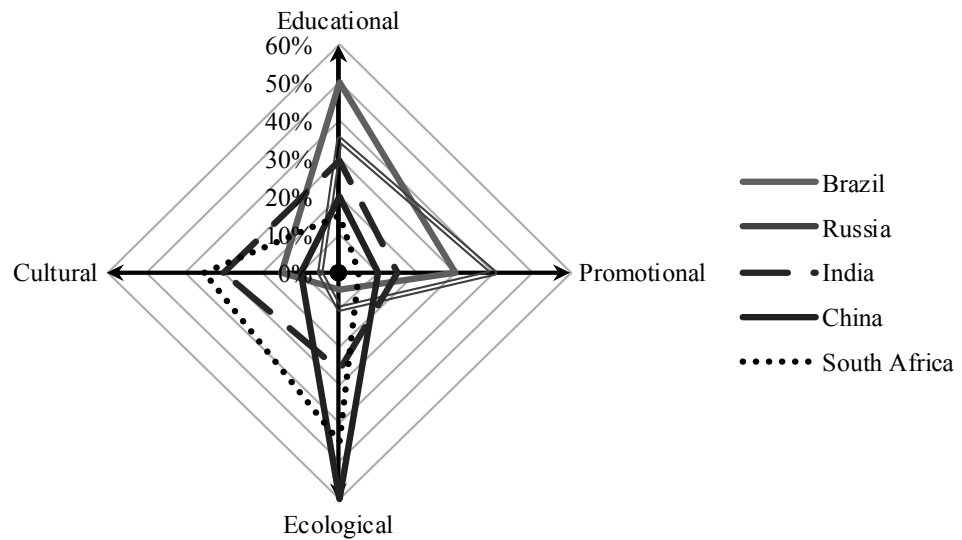

Zhanna Belyaeva

Business evolution in

the lens of universiti

sustainable impact:

Russian lessons in BRICS 
Sinergie

Vol. 35, N. 102, 2017

Despite the limitation in the universities' sample, the findings reflect several facts that can be interpreted as typical features of the evolving model of University Social Responsibility in BRICS universities.

Following the perceived contextual picture, it is possible to compare the extent of the implementation of different practices in 10 universities. Moreover, there is some evidence of prioritized directions within the? model. According to the results in fact, it is common for Chinese and South African universities to have a strong ecological impact on regions. Universities in India pay great attention to the cultural components of their activities. In addition, there are visible shifts towards the promotional group of factors in Russian and Brazilian universities. Considering Indian HEIs, there is a tendency towards the prevalence of cultural impacts.

Several drivers (factors), which explain the differences between these five models have been determined. Firstly, the USR model was formed as a response to the countries' cultural peculiarities. There is no questioning the fact that cultural traditions and customs have strong impact on most of the country's internal and external processes And the USR model is not an exception. For instance, a shift towards cultural aspects in India's model is a result of the perception of the significance of the country's customs, religions and traditions. Secondly, different economic development levels predetermine the priorities of the USR system. For instance, China has underwent rapid economic development but this success comes at the cost of environmental deterioration. China's environmental problems have therefore become more pronounced and discussed. Consequently, environmental protection is also the focus of China's development program and USR model. Moreover, diversity of government involvement and support explains differences in the BRICS universities' USR models. Therefore, models of USR are influenced by the countries' socio-economic and environmental peculiarities.

\section{Discussion and the Russian perspective}

As higher education institutions have become more complex and more important to the community, the University Social Responsibility concept is also becoming more important. There is a growing need for complete and accurate regional and international data for analysis as well. In BRICS understanding of the universities' innovative role in balancing a sustainable multistakeholder approach to regional development is not unified and varies between HEIs and other types of organizations.

The primary objective of this paper was to analyze the University Social Responsibility model of BRICS countries. The sample in this study is limited to ten BRICS universities that have implemented the social responsibility concept in its different stages. To access the crosscultural context of shared values and drivers for innovative models the authors have carried out a content analysis of the information resources of universities in accordance with a specifically predefined coding system including schedules, reports, development programs, guidelines etc. They 
have considered universities' impact on their home regions and defined the prioritized spheres of influence.

University social responsibility is an important aspect of how different universities interact with their internal and external stakeholders in BRICS countries. Universities play a potentially pivotal role in the social and economic development of their regions and are therefore important assets of the regions. In addition, universities in BRICS can act as connecting agents for the collaboration and interaction of students and graduates in order to obtain a synergistic effect for BRICS' future development.

Moreover, the BRICS Network University has recently been established. For Russian HEIs this joint project represents great opportunity to create unified educational environment, develop academic mobility and train highly qualified professionals in the areas of activity that are of high priority to member states.

The successful mobilization of university resources can have a positive effect on their regional economies and the achievement of comprehensive regional strategies.

It is also important to highlight that the practical implications of these findings are complex. Since BRICS are emerging as a new economic power, building the common subject area of these countries is of particular importance for academics, policy makers and business representatives. In order to find evidence of convergence in socially responsible practices among the five BRICS and further develop reasonable and useful recommendations for management, in this paper USR models in BRICS were compare. Despite considerable shifts in different directions of the driver-based model, there are several common characteristics such as the strong presence of environmental activities in South Africa and China and visible offset to the promotional group of factors in the cases of Russian and Brazilian universities.

The current situation in Russia highlights two strong and almost equal directions for the promotional (40\%) and educational (35\%) groups of factors. Most disclosed activities in Russian universities aimed at attracting and promoting HEIs. Some of the events and ideas were transmitted to society in order to raise awareness about universities among different groups of stakeholders like business representatives, local community and the government. This enables universities to create a specific brand image. Again, there is the issue of the interrelation between disclosure and commitment: if something has been disclosed, it does not necessarily mean that it has been done. In making a parallel between business units and HEIs, it should be mentioned, this problem is also common for the corporate sector of Russia.

To sum up, the following key functions of Russian universities may be enumerated when considering their new positions as socially responsible HEIs:

- Universities have the responsibility to train qualified specialists, who are going to work in prospective industries in a particular region;

- The level of graduates should meet the requirements of businesses; most students must have skills and knowledge related to sustainable management;
Zhanna Belyaeva
Victoria Bentsion

Business evolution in

the lens of universities

sustainable impact:

Russian lessons in BRICS 
sinergie Vol. 35, N. 102, 2017

- Universities should join different business-initiated or governmentinitiated projects connected with environmental issues and innovative development activities.

In order to respond to all of these challenges, Russian universities should assess their level of training (quality assurance) on a regular basis. In addition, the management model of HEIs requires changes.

The data is limited by its sample size. For future studies, an empirical analysis of the data is suggested in order to confirm the findings in this paper. Moreover, the present research could be expanded to include more universities in various countries. Another direction of further research could involve a comparison among countries in order to reveal the main differences between emerging economies and developed economies.

\section{References}

BELYAEVA ZH. S. (2015), "Systemic approach to social responsibility: building and mapping sustainable practices at Ural Federal University", The $8^{\text {th }}$ EuroMed conference of the EMAB proceedings, Verona, Italy, pp. 158-170.

BEREZO D.J., DE LA CRUZ AYUSO C., SASIA SANTOS P.M. (2008), "Strategic local responses to global governance: the case of xertatu", Corporate Governance: The international Journal of Business in Society, vol. 8, n. 4, pp. 571-577.

ELKINGTON J. (1998), "Partnerships from cannibals with forks: The triple bottom line of 21st-century business", Environmental Quality Management, vol. 8 n. 1, pp. 37-51.

ESFIJANI A., HUSSAIN F., CHANG E. (2013), "University social responsibility ontology", International Journal of Engineering Intelligent Systems, vol. 21, n. 4 , pp. $271-281$.

ETZKOWITZ H. (2012), "Triple helix clusters: boundary permeability at university-industry-government interfaces as a regional innovation strategy", Environment and Planning C: Government and Policy, vol. 30, n. 5, pp. 766-779.

GOMEZ L. (2014), “The Importance of University Social Responsibility in Hispanic America: A Responsible Trend in Developing Countries", Corporate Social Responsibility and Sustainability: Emerging Trends in Developing Economies (Critical Studies on Corporate Responsibility, Governance and Sustainability, vol. 8) Emerald Group Publishing Limited, pp. 241-268.

GRAEDEL T.E. (2002), "Quantitative sustainability in a college or university setting", International Journal of Sustainability in Higher Education, vol. 2, n. 4, pp. 346-358.

HIGHER EDUCATION AND REGIONS: GLOBALLY COMPETITIVE, LOCALLY ENGAGED, OECD [online] Available at: http://www. oecd. org/edu/imhe/39378517. pdf [Accessed 21 September 2015] UNESCO’s Global Education Digest [online] Available at: http://unesdoc. unesco. org/ images/0018/001832/183249e. pdf [Accessed 21 September 2015]

KOSCHATZKY K., STAHLECKER T. (2010), "New forms of strategic research collaboration between firms and universities in the German research system", International Journal of Technology Transfer and Commercialisation, vol. 9, n. 1-2, pp. 94-110. 
LOZANO R. (2006), “Incorporation and institutionalization of SD into universities: breaking through barriers to change", Journal of Cleaner Production, vol. 14, n. 9, pp. 787-796.

MADEIRA A.C., CARRAVILLA M.A, OLIVEIRA J.F., COSTA C. (2011), "A Methodology for sustainability evaluation and reporting in Higher Education Institutions", Higher Educations Policy, vol. 24, n. 4, pp. 459-479.

DEL GIUDICE M., CARAYANNIS E. G., DELLA PERUTA M.R. (2012), "CrossCultural Knowledge Management Fostering Innovation and Collaboration Inside the Multicultural Enterprise", Innovation, Technology, and Knowledge Management, vol. 11, p. 166

MATTEN D., MOON J. (2004), "Corporate social responsibility education in Europe", Journal of Business Ethics, vol. 54, n. 4, pp. 323-337.

MOWERY D.C., SAMPAT B.N. (2005), "The Bayh-Dole act of 1980 and universityindustry technology transfer: a model for other OECD governments?", The Journal of Technology Transfer, vol. 30, n. 1-2, pp. 115-127.

NEJATI M., SHAFAEI A., SALAMZADEH Y., DARAEI M. (2011), "Corporate social responsibility and universities: A study of top 10 world universities' websites", African Journal of Business Management, vol. 5, n. 2, pp. 440-447.

PERIC J. (2012), “Development of universities' social responsibility through academic service learning programs", Economy of eastern Croatia yesterday, today, tomorrow, vol. 1, pp. 365-375.

STARK W., STÖCKMANN K., TEWES S. (2014), A need to fill the gap: is there enough "institutional social responsibility" (ISR) in German universities?, University of Duisburg-Essen, Germany.

UNESCO, (2011), Global education digest 2011, Comparing education statistics across the world.

VASILESCU R., BARNA C., EPURE M., BAICU C. (2010), “Developing university social responsibility: a model for the challenges of the new civil society", Procedia social and Behavioral Sciences, vol. 2, n. 1 pp. 4177-4182.

VELAZQUEZ L., MUNGUIA N., SANCHEZ M. (2005), "Deterring sustainability in higher education institutions: An appraisal of the factors which influence sustainability in higher education institutions", International Journal of Sustainability in Higher Education, vol. 6, n. 9, pp. 383-391.

ZOU Y., ZHAO W., MASON R., LI M. (2015), "Comparing Sustainable Universities between the United States and China: Cases of Indiana University and Tsinghua University", Sustainability, vol. 7, n. 9, pp. 11799-11817.
Zhanna Belyaeva

Business evolution in

the lens of universities

sustainable impact:

Russian lessons in BRICS 
sinergie

Vol. 35, N. 102, 2017

http://spbu.ru

http://www.urfu.ru

http://www.tsinghua.edu.cn

http://www.uct.ac.za

http://www.uj.ac.za

University of Essex http://www.essex.ac.uk/

QS Universities Rankings https://www.topuniversities.com/university-rankings

\section{Academic or professional position and contacts}

\section{Zhanna Belyaeva}

Associate Professor in International Business and C(U)SR

Ural Federal University (Russia)

e-mail: zh.s.belyaeva@urfu.ru

\section{Victoria Bentsion}

Lecturer and Research Fellow in International Business and USR

Ural Federal University (Russia)

e-mail: victoriabentsion@gmail.com

sinergie

ISSN 0393-5108 DOI $10.7433 /$ s102.2017.06 pp. $65-84$

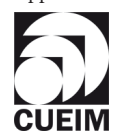

